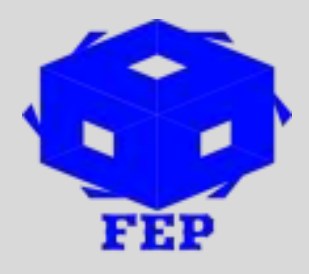

\title{
ASSESSING STUDENT SATISFACTION OF COLLEGE OF SOCIAL SCIENCES AND HUMANITIES, JIMMA UNIVERSITY \\ Temesgen Alemu Terfa ${ }^{1}$ \\ ${ }^{1}$ Jimma University, Department of Journalism and Communication
}

*Corresponding Author: Temesgen Alemu Terfa

Corresponding Author Email: talemu43@gmail.com

Article Received: 22-03-19 Accepted: $31-03-19$

Published: 05-04-19

Licensing Details: Author retains the right of this article. The article is distributed under the terms of the $\begin{array}{lllll}\text { Creative } & \text { Commons } & \text { Attribution-NonCommercial } & 4.0 & \text { Licence }\end{array}$ (http://www.creativecommons.org/licences/by-nc/4.0/) which permits non-commercial use, reproduction and distribution of the work without further permission provided the original work is attributed as specified on the Journal open access page.

\begin{abstract}
The present paper aims to assess the student satisfaction of Jimma University, College of Social Sciences and Humanities. The satisfaction level of students with teaching and learning service and the factors affecting the satisfaction level of students of the college were the key objectives. Questionnaire and focus group discussion were used to gather the necessary data from the respondents. A closed questionnaire containing 38 items categorized in four sections has been used. These questions were related with academic staff, academic advising/mentorship, assessments, and student services. Besides, ten (10) representative students from the college were purposively selected for focus group discussions. A Likert-type response scale has been employed to measure the data gathered through questionnaires. SPSS software has been used for data analysis of the questionnaire. General survey guided by well-structured questionnaire through simple random sampling has been administered across a sample of 317 students. The collected data were analyzed both quantitatively and qualitatively and the finding of the study indicated that there is moderate satisfaction level of students with the services that were delivered by the college. Therefore, it is recommended that the college authorities should take the necessary measures in order to increase the students' satisfaction level.
\end{abstract}

Keywords: Satisfaction, Service, Student, Teaching and learning 


\section{INTRODUCTION}

Education in general and quality education in particular plays a very important role in bringing about the desired development of a country. Similarly, the sustainability of the success and wellbeing of any society depends on its students who are the valuable and essential part of the society. The objectives of higher education are to provide in-depth knowledge, educate students, seek academic development, and coordinate national development demands (Johnes and Taylor, 1990). Universities as providers of academic services are of great importance in any society since the progress of a society depends on its universities. It is a place where the members of society are educated and enlightened. The students who seek to acquire knowledge and start working after graduation make a significant contribution to the development of industry in the society. As a result, the quality of services is of great significance. The level of students' satisfaction with educational and welfare services in the university greatly contribute to the quality education in the university.

Students' satisfaction surveys are important in ascertaining whether colleges and universities are fulfilling their mission. It is well known that the most important product of educational institutions is qualified graduates. In order to best prepare students so that they are sought after by employers upon graduation. Students must understand the value of their education and be satisfied with their overall experience in order to promote and support their higher educational institution as a student and as an alumnus. Satisfaction is a relevant measure because many studies have demonstrated that other factors being equal, satisfied individuals are likely to be willing to exert more effort than unsatisfied individuals (Bryant, 2006; Özgüngör, 2010).

What is more, satisfied students are more likely to be committed and continue their studies (as measured by a higher retention rate) than unsatisfied students, who are likely to be less willing to regularly attend classes, and are more likely to quit their studies (Jamelske, 2009; Borden, 1995). Thus, satisfied students are likely to exert more effort in their educational studies by taking actions such as regularly attending their classes and becoming more involved in their coursework and institution. It is necessary to conduct scientific study to understand the satisfaction level of students.

\section{STATEMENT OF THE PROBLEM}

So far, various studies indicated that the satisfaction issue became an important concern. So long as university is an institution providing service, it needs to conduct a study to assess the satisfaction level of its customers, its students for this case. Focusing on student satisfaction enables universities to gauge how effectively they meet or exceed student needs. Researchers such as Cheong Cheng \& Ming Tam (1997) and Coskun (2014) found that to be recognised as a service providing industry, higher education has to meet the needs and expectations of its students. In line with this concept, it is vital to carry out a study to identify the satisfaction level of the students of the college of social sciences and humanities found at Jimma University. More to the point, as far as the researcher knowledge is concerned, there is no study conducted on this issue at the stated college level of the university. Hence, this study was intended to fill the gap. 


\section{OBJECTIVE OF THE STUDY \\ General Objective}

The general objective of the study is to assess the satisfaction level of undergraduate students enrolled in regular program of Jimma University, College of Social Sciences and Humanities.

\section{Specific objectives}

1. To measure students satisfaction level with teaching and learning service of the college of social sciences and humanities of Jimma University.

2. To find out the factors affecting on the satisfaction level of students of the college.

\section{RESEARCH QUESTIONS}

The study attempted to answer the following research questions.

I. What is the satisfaction level of students with teaching and learning service of the college of social sciences and humanities of JU?

II. What are the factors affecting the satisfaction of the students of the college?

\section{THEORETICAL FRAMEWORK OF THE STUDY}

In order to achieve success, an institution is supposed to understand and fulfill the needs of its customers. The most widely used model known as SERVQUAL was developed first in 1985 by Parasuraman et al to measure the service quality of an organization. Parasuraman (1985) identified ten core components of service quality as reliability (consistent performance and dependability),responsiveness (willingness /readiness to serve), competence (possessing knowledge and skills), access (approachability and ease of contact), curtsy ( politeness, consideration and friendliness of staff), communication ( updating and listing to customers), as well as tangibles (facilities and physical features). Thus, SERVQUAL model is employed inn this study to measure the services delivered to the students by the college have been gauged in this specific study along with the factors affecting the services.

\section{METHODOLOGICAL APPROACH}

Mixed research approach was used to evaluate the satisfaction level of CSSH students on teaching and learning process. As Creswell (2003) stated mixed approach use both qualitative and quantitative methods to make comprehensive analysis. The study used students of all departments from the college of social sciences and humanities of Jimma University as primary data source. questionnaires and focus group discussions were used to gather necessary information from the primary source of data.

The total population of the study is all the regular students of college of social sciences and humanities of Jimma University. Since the population is homogenous in nature, simple random sampling technique was used for questionnaire method of data collection and judgmental sampling for focus group discussions. Accordingly, using simple random sampling questionnaires were distributed for all respondents that were included in the sample size of the study. the sample size of this study was determined by Yamane Taro's. (1967) sample size determination formula. That is; 


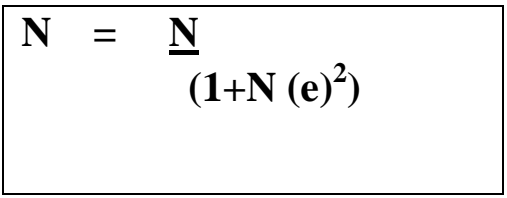

Where

N- Represents total population

n- Represents Sample size

e- is acceptable level of sampling error (for example in this study case, at $\mathbf{9 5 \%}$ level of confidence, the sampling error is acceptable up to 5\%).

Using the above formula, the following sample size was set in the form table

\begin{tabular}{|l|l|l|l|l|}
\hline Name & Total population & $\begin{array}{l}\text { proportion of } \\
\text { sample }\end{array}$ & $\begin{array}{l}\text { Expected } \\
\text { sample size }\end{array}$ & Sample units \\
\hline Students & 1540 & $1540 / 317=0.9$ & 317 & If $150 / 1540 * 317=30$ \\
\hline
\end{tabular}

Therefore, the sample size of this study was 317.

In addition, judgmental (purposive) sampling was used to make focus group discussion representative of the students who had more contacts with administrative and academic staffs of the college, thus; they were expected know more about the service that are delivered to the students in general than the other students.

Once the responses have been collected from the respondents, the researcher analyzed the data in order to get a clear understanding. To explore the level of satisfaction, the researchers employed a five point likert scale that have range from strongly satisfied to strongly dissatisfied to measure the students' level of satisfaction. Descriptive statistics is employed to analyze the data by using SPSS. The analyzed data then presented in tables and graphs format. The focus group discussions were analyzed thematically. The two formats were used to get a clear understanding of the data collected.

\section{DATA ANALYSIS AND INTERPRETATION}

The collected data through questionnaires and focus group discussion from total 324 populations were analyzed and presented both in numeric and words.

The Demography of the Respondents

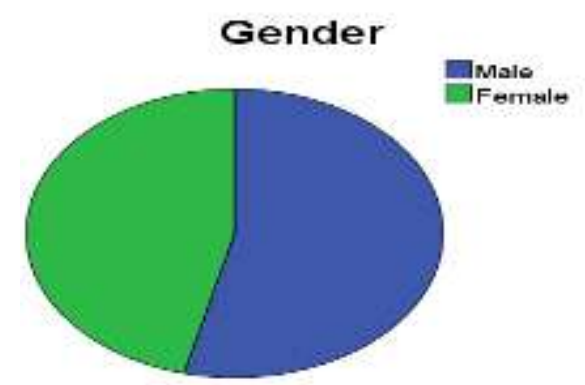

Figure 1: Chart 1.1 Gender figure of the respondants 
As indicated in the above chart, majority of the respondents are male students (53.9\%) and female students are about $46.1 \%$. From this it is possible to deduce that though the majority of students in the college are male, however, though female respondents are few in number, the researcher tried to use as many female respondents as possible.

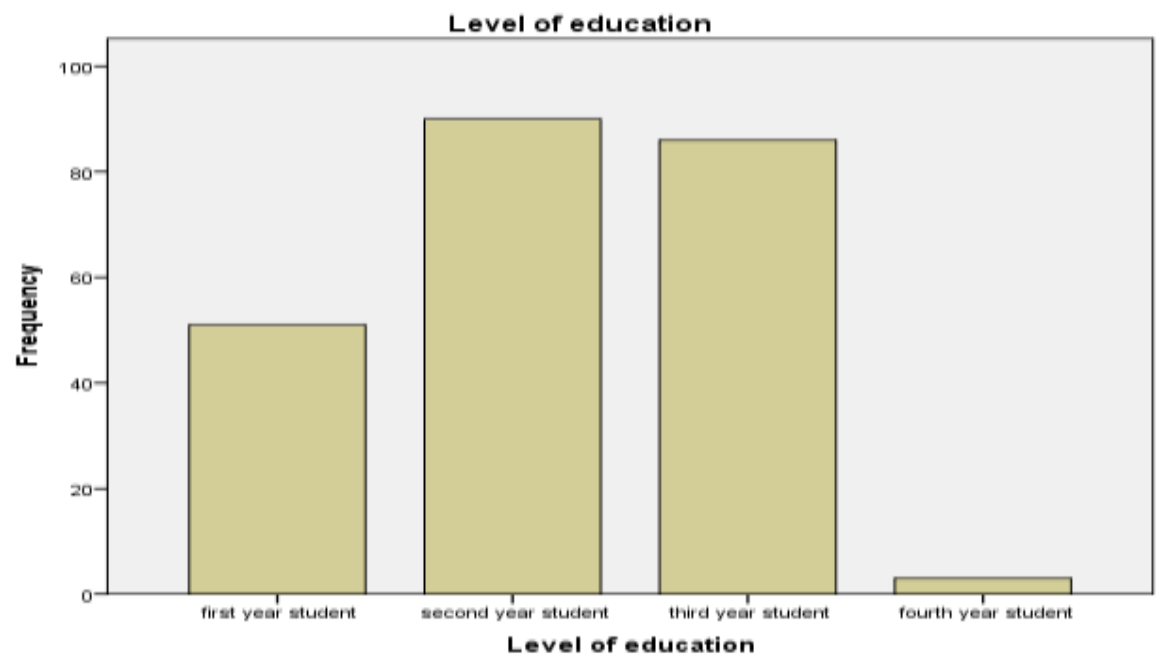

Figure 2: Bar-chart 1.1. Duration of students in the university

As indicated in the above bar chart, an attempt was made to include all the regular undergraduate students of all departments to assess their satisfaction. As it is seen above, the frequencies vary since the number of students found in different batches is also different. The numbers of fourth year students are very few because there is no fourth batch in the college except music department.

Table 1.1 Field of Education

\begin{tabular}{|l|l|l|l|l|}
\hline Department & Frequency & Percent & Valid Percent & Cumulative Percent \\
\hline Afan Oromo & 33 & 14.3 & 14.3 & 14.3 \\
\hline Folklore & 19 & 8.3 & 8.3 & 22.6 \\
\hline Sociology & 16 & 7.0 & 7.0 & 29.6 \\
\hline English Lang. & 27 & 11.7 & 11.7 & 41.3 \\
\hline Amharic & 15 & 6.5 & 6.5 & 47.8 \\
\hline Geography & 49 & 21.3 & 21.3 & 69.1 \\
\hline History & 25 & 10.9 & 10.9 & 80.0 \\
\hline Music & 4 & 1.7 & 1.7 & 81.7 \\
\hline Social Work & 24 & 10.2 & 10.2 & \\
\hline Theatre & 18 & 7.8 & 7.8 & 92.3 \\
\hline & & & & 99.1 \\
\hline Total & 230 & 100.0 & 100.0 & \\
\hline
\end{tabular}

According to the above table, the questionnaire was distributed to all departments found in the college of social sciences and humanities to assess their satisfaction. The table also indicates that the percentage varies across the departments. This is because of the fact that number of students 
found in each department varies even there are departments which have two sections. This was the main reason why the questionnaire was distributed according to the number of respondents found in each department so that it gives fair chance of distribution.

Table 2: Satisfactions with Academic Staff

\begin{tabular}{|c|c|c|c|c|c|c|c|c|}
\hline No. & Satisfactions with Academic Staff & & $\begin{array}{l}\text { Very } \\
\text { Dissatisfied }\end{array}$ & Dissatisfied & Neutral & Satisfied & $\begin{array}{l}\text { Very } \\
\text { Satisfied }\end{array}$ & Total \\
\hline \multirow[t]{2}{*}{1} & \multirow{2}{*}{$\begin{array}{l}\text { The instructors clearly explain } \\
\text { course goals and requirement at } \\
\text { the very beginning }\end{array}$} & Count & - & 13 & 66 & 100 & 51 & 230 \\
\hline & & $\%$ & - & 5.7 & 22.2 & 43.5 & 28.7 & $100 \%$ \\
\hline \multirow[t]{2}{*}{2} & \multirow{2}{*}{$\begin{array}{l}\text { The instructors make their } \\
\text { subjects interesting using } \\
\text { different teaching methods }\end{array}$} & Count & 18 & 75 & 71 & 49 & 17 & 230 \\
\hline & & $\%$ & 7.8 & 32.6 & 30.9 & 21.3 & 7.4 & $100 \%$ \\
\hline \multirow[t]{2}{*}{3} & \multirow{2}{*}{$\begin{array}{ll}\text { The instructors } & \text { initiate } \\
\text { discussion in the class } & \end{array}$} & Count & 17 & 78 & 68 & 49 & 18 & 230 \\
\hline & & $\%$ & 7.4 & 33.9 & 29.6 & 21.3 & 7.8 & $100 \%$ \\
\hline \multirow[t]{2}{*}{4} & \multirow{2}{*}{$\begin{array}{l}\text { The instructors have contact } \\
\text { hours to have further discussions } \\
\text { with students }\end{array}$} & Count & 67 & 105 & 14 & 33 & 11 & 230 \\
\hline & & $\%$ & 29.1 & 45.7 & 6.1 & 14.3 & 4.8 & $100 \%$ \\
\hline \multirow[t]{2}{*}{5} & \multirow{2}{*}{$\begin{array}{l}\text { The instructors give feedback on } \\
\text { time to help for the next } \\
\text { assignment }\end{array}$} & Count & 24 & 73 & 72 & 43 & 18 & 230 \\
\hline & & $\%$ & 10.4 & 31.7 & 31.3 & 18.7 & 7.8 & $100 \%$ \\
\hline \multirow[t]{2}{*}{6} & \multirow{2}{*}{$\begin{array}{l}\text { The instructors lecture is } \\
\text { understandable and logical }\end{array}$} & Count & - & 16 & 34 & 97 & 83 & 230 \\
\hline & & $\%$ & - & 7 & 14.8 & 42.2 & 36.1 & $100 \%$ \\
\hline \multirow[t]{2}{*}{7} & \multirow{2}{*}{$\begin{array}{l}\text { The instructors seem well } \\
\text { prepared before they come to } \\
\text { class }\end{array}$} & Count & - & 9 & 27 & 107 & 87 & 230 \\
\hline & & $\%$ & - & 3.9 & 11.7 & 46.5 & 37.8 & $100 \%$ \\
\hline \multirow[t]{2}{*}{8} & \multirow{2}{*}{$\begin{array}{l}\text { The instructors welcome and } \\
\text { encourage questions } \\
\text { comments }\end{array}$} & Count & 25 & 73 & 59 & 52 & 21 & 230 \\
\hline & & $\%$ & 10.9 & 31.7 & 25.7 & 22.6 & 9.1 & $100 \%$ \\
\hline \multirow[t]{2}{*}{9} & \multirow{2}{*}{$\begin{array}{l}\text { The instructors treat all students } \\
\text { with respect }\end{array}$} & Count & 44 & 91 & 65 & 28 & 2 & 230 \\
\hline & & $\%$ & 19.1 & 39.6 & 28.3 & 12.2 & .9 & $100 \%$ \\
\hline \multirow[t]{2}{*}{10} & \multirow{2}{*}{$\begin{array}{l}\text { The instructors are cooperative } \\
\text { and encouraging }\end{array}$} & Count & 51 & 135 & 29 & 7 & 8 & 230 \\
\hline & & & 22.2 & 58.7 & 12.6 & 3.0 & 3.5 & $100 \%$ \\
\hline
\end{tabular}

From the above data in the table, it is possible to infer that the survey figure tends to show that students are dissatisfied with their teaching or academic staff though there are areas in which they are satisfied with. Majority of the students are dissatisfied with their instructors teaching methods because they do not encourage questions and discussions in the class rooms nor use different teaching aids to make their class interesting. According to the data given above, though students are satisfied with the instructors' preparation, they are dissatisfied with the instructors' feedback. Most students want to get their feedback on time to get prepared for their next assignments or tasks. However, their instructors keep students assignment with themselves for a long time. Similarly, majority of instructors do not have contact hours or else do not avail themselves according to the contact hours of their students. As a result, the students couldn't be able to discuss any problem they have with their instructors. As the data show, instructors do not treat all students with respect as a result many students agree that their instructors are not cooperative and encouraging. 
The data from the focus group discussion (from students) told that as the students of the college haven't good academic relationships with their teachers. According to the discussants suggestions, due to the fear and respect they have for their teachers they didn't develop a good academic relation with their teachers. As to discussants the method of teaching and the behavior of instructors are among the factors that can affect students- instructor's academic relationships. Discussants revealed as there is a gap in instructors and students relation in the college. They said, many teachers want to be seen as a boss not as a father. They detach themselves from having very smooth relationships with their students, though it may not work for all instructors. According to the discussants, this has to be improved. Student instructor relationship should be father and son relations.

With regard to the instructors mode of delivery, as to the discussants many instructors present the course plan clearly, but they believe that there are some problems in handling classes. As to them a university is a place where students get ready before they start a job. However, in the college of Social Sciences of Jimma University there is lack of practical session which may prepare students for the next life journey. Most of the time, the communication in the class is one way. There is no enough discussion in the class.

What is more, the discussants revealed that some instructors do not fairly treat top students and lower achiever students equally. They said instructors go with the tempo of top learners. Even some times they do not ask the other students whether they understood or not the content of the course. Both the qualitative and quantitative data revealed that majority of students of the college are dissatisfied in many areas about their academic or teaching staffs due to many factors.

Table 3. Satisfaction with Academic Advising or Mentorship

\begin{tabular}{|c|c|c|c|c|c|c|c|c|}
\hline No & $\begin{array}{l}\text { Questions related with academic } \\
\text { /mentorship }\end{array}$ & dvising & $\begin{array}{l}\text { Very } \\
\text { Dissatisfied }\end{array}$ & Dissatisfied & Neutral & Satisfied & $\begin{array}{l}\text { Very } \\
\text { Satisfied }\end{array}$ & Total \\
\hline \multirow[t]{2}{*}{1} & \multirow[t]{2}{*}{ My academic advisor is approachable } & Count & 28 & 66 & 65 & 48 & 23 & 230 \\
\hline & & $\%$ & 12.2 & 28. & 28.3 & 20.9 & 10.0 & $100 \%$ \\
\hline \multirow[t]{2}{*}{2} & \multirow{2}{*}{$\begin{array}{l}\text { My academic advisor is concerned } \\
\text { about my success }\end{array}$} & Count & 53 & 57 & 69 & 31 & 20 & 230 \\
\hline & & $\%$ & 23.0 & 24.8 & 30.0 & 13.5 & 8.7 & $100 \%$ \\
\hline \multirow[t]{2}{*}{3} & \multirow{2}{*}{$\begin{array}{l}\text { My academic advisor has adequate time } \\
\text { to spend with me }\end{array}$} & Count & 32 & 131 & 45 & 19 & 3 & 230 \\
\hline & & $\%$ & 13.9 & 57.0 & 19.6 & 8.3 & 1.3 & $100 \%$ \\
\hline \multirow[t]{2}{*}{4} & \multirow{2}{*}{$\begin{array}{l}\text { My academic advisor guides me all the } \\
\text { way through my learning difficulties }\end{array}$} & Count & 37 & 80 & 63 & 36 & 14 & 230 \\
\hline & & $\%$ & 16.1 & 34.8 & 27.4 & 15.7 & 6.1 & $100 \%$ \\
\hline \multirow[t]{2}{*}{5} & \multirow{2}{*}{$\begin{array}{l}\text { My academic advisor gives me } \\
\text { sufficient information about matters } \\
\text { related to my studies }\end{array}$} & Count & 40 & 83 & 61 & 26 & 20 & 230 \\
\hline & & $\%$ & 17.4 & 36.1 & 26.5 & 11.3 & 8.7 & $100 \%$ \\
\hline \multirow[t]{2}{*}{6} & \multirow{2}{*}{$\begin{array}{l}\text { My advisor gives me accurate } \\
\text { information about the College's } \\
\text { policies, procedures, resources and } \\
\text { programs }\end{array}$} & Count & 27 & 78 & 63 & 40 & 22 & 230 \\
\hline & & $\%$ & 11.7 & 33.9 & 27.4 & 17.4 & 9.6 & $100 \%$ \\
\hline \multirow[t]{2}{*}{7} & \multirow{2}{*}{$\begin{array}{l}\text { My advisor assist me in developing } \\
\text { educational plans }\end{array}$} & Count & 66 & 102 & 44 & 18 & - & 230 \\
\hline & & $\%$ & 28.6 & 44.3 & 19.1 & 7.8 & - & $100 \%$ \\
\hline
\end{tabular}


According to the above table, it is possible to understand that students of the college are dissatisfied with their academic advisors in different aspects. The academic mentors are not approachable. As different scholars believe student-instructor relationships has a positive outcome on students' satisfaction. While Palmer and Holt (2008) suggested that the interaction between teacher and student has positive relation to student satisfaction. The above data also revealed that their academic mentors do not provide information with regard to the teaching learning processes and policies of the college as well. Likewise, the academic mentors do not spend adequate time with their students nor help them in preparing educational plans. According to Nasurdin, 2006; Tessema, Ready and Embaye, 2011), in academic settings, satisfaction has been defined as the extent to which students are satisfied with a number of college-related issues such as advising, quality of instruction, course availability, and class size. From this one can understand that the issue of advising in academic setting is one of the pillars for students' academic satisfaction.

The data from focus group discussion revealed that students in most departments do not have an academic advisor or mentor. Many of the discussants complained about academic advisor. As to them students do not have academic advisor who mentor students about academic issues. Even they didn't hear the name academic advisor in the college. They get information from each other especially from their senior students. Correspondingly, the discussants discovered that they didn't see any department in the college guiding students to prepare course target plan. It is up to individual student to study hard and score a good grade. Therefore, from both data which are the quantitative and qualitative it is possible to deduce that some departments even do not know the name academic advisor whereas the other departments do not actually put in to practice so as to help students of the college. As a result students are dissatisfied with their academic advisor or mentor.

Table: 4 Satisfaction with Assessment or Course Evaluation

\begin{tabular}{|c|c|c|c|c|c|c|c|c|}
\hline No & $\begin{array}{l}\text { Questions related with assessment } \\
\text { evaluation }\end{array}$ & or course & $\begin{array}{l}\text { Very } \\
\text { Dissatisfied }\end{array}$ & Dissatisfied & Neutral & Satisfied & Very Satisfied & Total \\
\hline \multirow[t]{2}{*}{1} & \multirow{2}{*}{$\begin{array}{l}\text { The assessment method is suitable } \\
\text { to measure your knowledge. }\end{array}$} & Count & 4 & 30 & 39 & 94 & 63 & 230 \\
\hline & & $\%$ & 1.7 & 13.0 & 17.0 & 40.9 & 27.4 & $100 \%$ \\
\hline \multirow[t]{2}{*}{2} & \multirow{2}{*}{$\begin{array}{l}\text { The assignments are relevant and } \\
\text { useful }\end{array}$} & Count & 1 & 18 & 47 & 98 & 66 & 230 \\
\hline & & $\%$ & 4 & 7.8 & 20.4 & 42.6 & 28.7 & $100 \%$ \\
\hline \multirow[t]{2}{*}{3} & \multirow{2}{*}{$\begin{array}{l}\text { I know how I am going to be } \\
\text { assessed }\end{array}$} & Count & 6 & 38 & 28 & 87 & 71 & 230 \\
\hline & & $\%$ & 2.6 & 16.5 & 12.21 & 37.8 & 30.9 & $100 \%$ \\
\hline \multirow[t]{2}{*}{4} & \multirow{2}{*}{$\begin{array}{l}\text { The assessments are vary and at } \\
\text { appropriate interval }\end{array}$} & Count & 5 & 52 & 73 & 71 & 29 & 230 \\
\hline & & $\%$ & 2.2 & 22.6 & 31.7 & 30.9 & 12.6 & $100 \%$ \\
\hline \multirow[t]{2}{*}{5} & \multirow{2}{*}{$\begin{array}{l}\text { I receive useful feedback on my } \\
\text { assessment }\end{array}$} & Count & 26 & 62 & 66 & 58 & 18 & 230 \\
\hline & & $\%$ & 11.3 & 27.0 & 28.7 & 25.2 & 7.8 & $100 \%$ \\
\hline \multirow[t]{2}{*}{6} & \multirow{2}{*}{$\begin{array}{l}\text { The evaluation procedures are fair } \\
\text { and balanced }\end{array}$} & Count & 7 & 32 & 52 & 97 & 42 & 230 \\
\hline & & $\%$ & 3.0 & 13.9 & 22.6 & 42.2 & 18.3 & $100 \%$ \\
\hline
\end{tabular}




\begin{tabular}{|l|l|l|l|l|l|l|l|l|}
\hline 7 & $\begin{array}{l}\text { The study load is appropriate for } \\
\text { the time of the course }\end{array}$ & Count & 35 & 119 & 49 & 23 & 4 \\
\cline { 3 - 9 } & & $\%$ & 15.2 & 51.7 & 21.3 & 10.0 & 1.7 \\
\cline { 3 - 9 } & $\%$ & 21.3 & 47.8 & 18.3 & 12.2 & .4 & $100 \%$ \\
\hline
\end{tabular}

From the above data in the table, it is possible to deduce that majority of the students are satisfied by the assessment method of the college. However, the students didn't by pass to reflect their feelings on inappropriate the study load for the time of the course. As the data from focus group discussion shows most courses are being offered in block mode of delivery. This has got many problems to both instructors and students as well. As to the discussants, Students become too busy and fail to understand the content of the course. In line with this, Qi et al. (2010) also commented on the teacher competencies, workplace attitude and curriculum have direct positive relation to student satisfaction. Based on the given data though the majority of the instructors of the college use relevant and useful assessments which measure students' knowledge, they didn't give feedback for students on time which will help students to prepare for the other tasks.

As the data from focus group discussions show the assessment system of majority instructors is good for students. As to the discussants many instructors assess students in variety of ways. If students fail in one assessment, they will have another chance to improve themselves. The discussants have the same stand on usefulness and appropriateness of the assessment at appropriate interval. However, discussants are not happy by the feedbacks from their instructors. Majority of the instructors do not give them a relevant feedback on time for students. They keep the assignments with themselves; they do not return it back on time. Similarly, the discussants are not happy by the study load. According to them it is difficult to get excellent learning experience for majority of their courses are delivered on block mode of delivery. For them to meet the deadline every teacher and student keeps running and the whole semester ends like this.

The discussants suggested improvements with regard to the delivery mode of many departments in the college for it affects the quality of education. Similarly, though the majority of instructors are good in assessment, they are advised to give the feedback on time so that it will help students for the other tasks. Generally, the data both from questionnaire and focus group discussion reveal that majority of the students are satisfied with some suggested improvements.

Table 5: Satisfaction With Administrative and Student Services

\begin{tabular}{|c|c|c|c|c|c|c|c|c|}
\hline No & $\begin{array}{l}\text { Questions related with administ } \\
\text { student services }\end{array}$ & ative and & $\begin{array}{l}\text { Very } \\
\text { Dissatisfied }\end{array}$ & Dissatisfied & Neutral & Satisfied & Very Satisfied & Total \\
\hline \multirow[t]{2}{*}{1} & \multirow{2}{*}{$\begin{array}{l}\text { Administrators of the college are } \\
\text { approachable to students }\end{array}$} & Count & 36 & 68 & 63 & 47 & 16 & 230 \\
\hline & & $\%$ & 15.7 & 29.6 & 27.4 & 20.4 & 7.0 & $100 \%$ \\
\hline \multirow[t]{2}{*}{2} & \multirow{2}{*}{$\begin{array}{l}\text { The college shows concern for } \\
\text { each individual student }\end{array}$} & Count & 25 & 77 & 84 & 44 & - & 230 \\
\hline & & $\%$ & 10.9 & 33.5 & 36.5 & 19.1 & - & $100 \%$ \\
\hline \multirow[t]{2}{*}{3} & \multirow{2}{*}{$\begin{array}{l}\text { There is a good range of fields } \\
\text { provided by the college }\end{array}$} & Count & - & 45 & 49 & 92 & 44 & 230 \\
\hline & & $\%$ & - & 19.6 & 21.3 & 40.0 & 19.1 & $100 \%$ \\
\hline \multirow[t]{2}{*}{4} & \multirow{2}{*}{$\begin{array}{l}\text { The college gives } \\
\text { information during } \\
\text { orientation }\end{array}$} & Count & 24 & 67 & 70 & 50 & 19 & 230 \\
\hline & & $\%$ & 10.4 & 29.1 & 30.4 & 21.7 & 8.3 & $100 \%$ \\
\hline
\end{tabular}




\begin{tabular}{|c|c|c|c|c|c|c|c|c|}
\hline & week and afterwards & & & & & & & \\
\hline \multirow[t]{2}{*}{5} & \multirow{2}{*}{$\begin{array}{l}\text { I get the opportunity to register for } \\
\text { field of my interest }\end{array}$} & Count & 31 & 71 & 67 & 39 & 22 & 230 \\
\hline & & $\%$ & 13.5 & 30.9 & 29.1 & 17.0 & 9.6 & $100 \%$ \\
\hline \multirow[t]{2}{*}{6} & \multirow{2}{*}{$\begin{array}{l}\text { Registration process of the college } \\
\text { is simple and active }\end{array}$} & Count & - & 33 & 59 & 83 & 55 & 230 \\
\hline & & $\%$ & - & 14.3 & 25.7 & 36.1 & 23.9 & $100 \%$ \\
\hline \multirow[t]{2}{*}{7} & \multirow{2}{*}{$\begin{array}{l}\text { The politeness of staff involved in } \\
\text { registration process is interesting }\end{array}$} & Count & 24 & 74 & 68 & 43 & 21 & 230 \\
\hline & & $\%$ & 10.4 & 32.2 & 29.6 & 18.7 & 9.1 & $100 \%$ \\
\hline \multirow[t]{3}{*}{8} & \multirow{3}{*}{$\begin{array}{l}\text { College staffs are kind and } \\
\text { supportive }\end{array}$} & Count & 19 & 73 & 72 & 47 & 19 & 230 \\
\hline & & $\%$ & 8.3 & 31.7 & 31.3 & 20.4 & 8.3 & $100 \%$ \\
\hline & & $\%$ & 8.7 & 30.0 & 36.5 & 17.4 & 7.4 & $100 \%$ \\
\hline \multirow[t]{2}{*}{9} & \multirow{2}{*}{$\begin{array}{l}\text { The college gives immediate and } \\
\text { appropriate feedback for students }\end{array}$} & Count & 44 & 97 & 31 & 38 & 20 & 230 \\
\hline & & $\%$ & 19.1 & 42.2 & 13.5 & 16.5 & 8.7 & $100 \%$ \\
\hline \multirow[t]{2}{*}{10} & \multirow{2}{*}{$\begin{array}{l}\text { The college has readily available } \\
\text { channels of expressing complaints } \\
\text { and comments }\end{array}$} & Count & 21 & 77 & 71 & 38 & 23 & 230 \\
\hline & & $\%$ & 9.1 & 33.5 & 30.9 & 16.5 & 10.0 & $100 \%$ \\
\hline \multirow[t]{3}{*}{11} & \multirow{3}{*}{$\begin{array}{l}\text { The number of students and } \\
\text { enough classroom facilities in a } \\
\text { class is appropriate for teaching } \\
\text { and learning process }\end{array}$} & Count & - & 37 & 37 & 96 & 60 & 230 \\
\hline & & $\%$ & - & 16.1 & 16.1 & 41.7 & 26.1 & $100 \%$ \\
\hline & & $\%$ & 1.3 & 11.7 & 16.1 & 38.3 & 32.6 & $100 \%$ \\
\hline
\end{tabular}

As it can be comprehended from the table above, students have moderate satisfaction on issues related with administrative and student services. Most students are dissatisfied as the college administrators are not approachable and politeness of staff involved in registration is not interesting. Besides, as the data imply that majority of students have the problem of getting sufficient information during orientation week and afterwards for their day to day activities in the college. Sometimes when students want to express their complaints to the concerned body, there is no readily available channel and also difficult for the students to get feedback for their questions. As Zeithaml aid responsiveness is the willingness to help customers and to provide prompt service. This dimension emphasizes attentiveness and promptness in dealing with customers request, questions, complaints, and problems. Responsiveness is communicated to customers by the length of time they have to wait for assistance, answers to questions, or attention to problems. Responsiveness also captures the notion of flexibility and ability to customize the service to customers need (Zeithaml et.al., 2006). As responsiveness is the one of the basic requirements for satisfaction students suggested the college for improvement.

On the other hand, many students are happy in other aspects. Students are happy by the range of fields the college has though many students join fields of not their interest. The class size, classroom facilities and easy registration process of the college are among the things most students are satisfied with.

Data from focus group discussions with regard to services of the college show that there is no enough laboratory and practical sessions for the courses which need practical sessions. Most of the discussants are unhappy for they are studying many courses theoretically and they are afraid of the challenges awaiting them when they start work at different organizations. In flow of information in the college aspect, as to the discussants, they meet with the head of their departments may be once per semester even that one is also for evaluating instructors. However, as they said they had no regular meeting with the department heads or instructors. Therefore, as to them, there is no one who orients them about the teaching learning process and other academic 
issues at the college level. What is more, the discussants reflected that the registration process of the college is good. As to the respondents, the problem is with secretaries of the departments in the college; the secretaries do not respect students, even they insult students. Therefore, the college is supposed to give them training. To sum up, quantitative and qualitative data show the moderate satisfaction of students of the college with administration and services of the college.

\section{FACTORS AFFECTING STUDENTS' SATISFACTION}

In academic setting, there are lots of factors affecting students' satisfaction. As Corts et al. (2000) identified five factors affecting satisfaction with an academic department. In this regard, the data from focus group discussion revealed that there are factors affecting students' satisfaction in the college. As to the discussants one of the factors is the way instructors of the college are monitored. The discussants reported that there is a problem in monitoring instructors especially those who teach common courses. The discussants said most of the instructors do not come to class regularly and finish semester based course within one month.

The discussants of the study also reported as the course offering mode has brought a serious problem on their teaching and learning process. According to the data from focus group discussions, the study load is in appropriate with the time given. As to the discussants, to meet the tight time all they do is trying their best to finalize the courses as much as possible within the given time frame. For discussants, this is really the most challenging job. The absence or impracticality of academic advising, lack of relations between students and academic or administration staff of the college, absence of appropriate channels for expressing complaints and lack of scheduled contact hours from instructors are among the factors affecting students satisfaction in the college as the discussants mentioned.

\section{CONCLUSIONS AND RECOMMENDATIONS}

The findings of the study tend to confirm that there is a moderate student satisfaction in the college. According to the study, there are areas in which students are satisfied and dissatisfied as well. With regard to academic staff or teaching staff of the college, the findings of the study indicate that majority of the students are satisfied by the way the instructors explain the course goals and every requirements of the course at the very beginning. Many students are satisfied with assessment or course evaluation method of the college. The assessment methods of the college are suitable to measure students' knowledge and they are relevant and useful as well.

The findings of the study revealed that many students are satisfied with assessment or course evaluation method of the college. The assessment methods of the college are suitable to measure students' knowledge and they are relevant and useful as well.

However, the findings also revealed that students of the college are dissatisfied by the role instructors' of the college play to initiate discussions in the class and most of the instructors teaching style is lecture method. The study indicated that most instructors do not have contact hours so as to have further discussions with their students on academic related issues. Also, the study found that the study load is inappropriate for time of the course as a result most students and instructors rush to cover the course than focusing on understanding content of the course. 
With regard to academic advising or mentorship, most of the academic advisors in the college are not approachable to students. Students' academic advisors do not spend adequate time with students and do not guide students all the way through their learning difficulties.

With regard to administrative and student services, administrators of the college are not approachable to students. Based on the finding, students and administration of the college have no stage where to discuss the teaching and learning process. In contrary, the varieties field of study, the registration process, the number of students in a classroom and facilities in a classroom are among the areas found interesting to the students.

The results from the analysis tend to portray that the major factors that affect the satisfaction of the students of the college are among the following. Firstly, students' academic advising has a problem. In most departments there is no academic advising or even if there is academic advisor, it is not practical. Secondly, most instructors do not have contact hours to discuss with their students privately or in a group for any academic issues. Thirdly, the study load of many departments in the college is challenging to most students. According to the study, as modes of delivery of many courses are block, most students are dissatisfied since it affects their understanding. Fourthly, academic and administration staffs of the college are not approachable. As the data from focus group discussants indicate both an academic and admin staffs of the college do not have relations with students.

\section{Recommendations}

Thus, to increase the student satisfaction level of college of social sciences and humanities, Jimma University, the following measures need to be taken.

$>$ The college should revise the curriculum or mode of delivery of many courses in many departments so that students will study without any stress by understanding the content of the course.

$>$ The instructors of the college should have contact hours and discuss with their students separately or in a group.

$>$ The academic and admin staffs of the college should be approachable to students.

$>$ Students should be assigned an academic advisor who provides students relevant and useful information about the academic environment which helps students for academic success

$>$ Finally, the college should let students to express their complaints or comments by setting up various communication channels.

\section{References}

Briggs, S. (2006). An exploratory study of the factors influencing undergraduate studentchoice: The case of higher education in Scotland. Studies in Higher Education, 31(6), 705- 722.

Creswell, J.W. (2003) Research Design, Qualitative, Quantitative and Mixed Approaches. 2nd ed. Sage Publications.

Johnes, J. and Taylor, J. (1990), Performance Indicators in Higher Education: Buckingham, The Society for Research into Higher Education Open University Press, Buckingham. 
Chen, S.H., Yang, C.C., Shiau, J.Y. and Wang, H.H. (2006), "The development of an employee satisfaction model for higher education", The TQM Magazine, Vol. 18 No. 5, pp. 484500 .

Douglas, J., Douglas, A., \& Barnes, B. (2006). Measuring student satisfaction at a UKuniversity. Quality Assurance in Education, 14(3), 251-267.

Elliott, K. M., \& Shin, D. (2002). Student satisfaction: An alternative approach to assessing this important concept. Journal of Higher Education Policy and Management, 24(2), 197-209.

Kara, A. (2004). Business Student Satisfaction, Intentions and Retention in Higher Education: An Empirical Investigation. MEQ, 03(Fall 2004), 1-15.

Quinn, A. Lemay, G. Larsen, P. Johnson, D. M. (2009). "Service Quality in higher education", (2nd ed., vol. 20, pp. 139-152)

Ruben, B.D. (1995), Quality in Higher Education, Transaction Books, New Brunswick, NJ.

Sultan, P., \& Wong, H. Y. (2013). Antecedents and consequences of service quality in a higher education context: a qualitative research approach. Quality Assurance in Education,

21(1), 70-95.

Yamane, Taro. (1967). Statistics: An Introductory Analysis, 2nd Edition, New York: Harper and Row.

Zeithaml, V. A., Berry, L. L., \& Parasuraman, A. (1993). The nature and determinants ofcustomer expectations of service. Journal of the Academy of Marketing Science, 21(1) 